\title{
Evaluation of Magnetizing Irrigation Water Impacts on the Enhancement of Yield and Water Productivity for Some Crops
}

\author{
Nessrien Sayed Abdel Kareem \\ Water Use Optimization Department, Water Management and Irrigation System Research Institute, National Water Research Center, \\ Kanater El- Khayria- B. Code 13621-National Water Research Center Building, Egypt
}

\begin{abstract}
Magnetic water treatment is considered as one of many techniques used worldwide that affects plant growth and development. This study examines whether there are beneficial effects of magnetic treatment of irrigation water on yield and water productivity as well as water saving. Three experiments were performed involving three crops (eggplant, faba beans and tomato) with different salinity tolerance thresholds $\mathrm{EC}_{\mathrm{w}} \quad 0.7,1.1$ and $1.7 \mathrm{dS} / \mathrm{m}$, respectively. Two types of irrigation water were applied magnetically treated and non-magnetically treated. The experiments were carried out at Wadi EL Natroon station of Water Management Research Institute, El-Behira Governorate, Egypt during two sequentially winter seasons of 2015/2016 and 2016/2017 in a complete randomized design analysis with four replicates. There was a decrease of $\mathrm{pH}$ of the soil irrigated with magnetically treated water (MTW) compared with the non-MTW. The pH reached neutral values in some locations, especially the area cultivated with the faba beans ( $\mathrm{pH}$ between 7.05 and 7.08). Results showed significant increases of water productivity for the MTW compared with non-MTW equal to $1.65,1.88$ and 1.78 for eggplant, faba beans and tomato, respectively. It was also observed that the MTW affected the amounts of irrigation water added to different crops during its growing period. The percentages of water savings were $11 \%, 13.5 \%$ and $14.2 \%$ for eggplant, faba beans and tomato, respectively. As a result the net return increased by $1.97,3.0$ and 2.45 for the three crops, respectively.
\end{abstract}

Key words: Magnetic irrigation water, eggplant, faba beans, tomato, yield, water productivity.

\section{Introduction}

Scarcity of water is the biggest challenge facing most of the world, especially for countries in arid and semi-arid regions. Egypt is one of these countries. Water resources in Egypt are limited, which are represented by Egypt's share of Nile water of 55.5 billion cubic meters per year as the main resource. Surface-water resources originating from the Nile are now fully exploited, while groundwater resources are being brought into full production because of increasing the demand for fresh water for different uses. The agricultural sector consumes more than $85 \%$ of this water. Therefore, the main water resources

Corresponding author: Nessrien Sayed Abdel Kareem, Ph.D., research fields: irrigation systems, crop water requirements and water management. management policy is to maximize the usage of unconventional resources by applying new technologies and techniques that improve crop yield per unit of water used. It is important to recognize that when using brackish water for irrigation and selecting appropriate management, the total volume of a saline water supply cannot be beneficially consumed for crop production. Meanwhile the greater the water salinity, the less it can be consumed before the salt concentration becomes limiting. There have been many studies on the effects of irrigation with saline water on plant. Ayars et al. [1] mentioned that, use of high salinity water alone or mixed with low saline water has a role in increasing soil salinity, especially at the surface soil layer. Hakkwan et al. [2] concluded that, the continuous irrigation with saline water resulted in noticeable decrease in crop yields. 
Moreover, it was found that the use of saline irrigation water under greenhouse conditions stimulated $\mathrm{Na}^{+}$ accumulation in both soil and crops.

Magnetically treated water (MTW) is water which has been passed through a magnetic field (MF) prior to use. Magnetic water treatment is a technology used worldwide to overcome water salinity problems. This research was directed to answer the questions whether this technology is effective in Egypt? Is magnetic treatment of irrigation water considered as an appropriate alternative to improve water productivity and help in dealing with future water scarcity?

Many studies have been applied to evaluate the positive effect of magnetic treatment technique of irrigation water. Zhu et al. [3] concluded that soil wash of salts by MTW increased by 30\%-33\% than those used with normal water. The results obtained by Oleshko et al. [4] were precedence in opening the field for the use of magnetic techniques as a source of cheap energy in improving and increasing the sustainability of saline water for irrigation. Takachenko [5] reported that MTW has the ability to remove the effect of the salts accumulated in the soil (50\%-80\%) compared to untreated water (UW) (30\%). In laboratory experiments, Takachenko and Ojil [6] confirmed that by applying the magnetization technique to wheat seeds, the germination rate was $100 \%$ compared to $83 \%$ for non-magnetized seeds. Studies have also showed that using salt water after magnetical treatment led to dissolving salt compounds and converted it to ions, which removes the harmful impact on the plant, improves the properties of soil and reduces the damage of the salts accumulation by increasing the speed of washing and removes salts in the root zone $[7,8]$.

Aladjadjiyan [9] demonstrated that irrigation with magnetized water increased the growth rate of maize crop. Hasan et al. [10] found that, the use of salt water after magnetic treatment to produce sunflower has a significant effect in reducing the damage caused by saline water $(5.81 \mathrm{dS} / \mathrm{m})$. The yield decreased by $32 \%$ compared to $56 \%$ with the UW. Fahd et al. [11] showed that irrigation with saline water treated magnetically increased the production of maize crop by $15 \%$ compared to irrigation with same water without treatment. Al-Jothery and Abdulsada [12] clarified that, there is a significant effect of irrigation water treated magnetically on the weight of dry matter of maize crop. Maheshwari and Grewalm [13] investigated the effect of magnetic treatment on celery and pea crops and water productivity irrigated with various types of water (MTW, UW, tap water, recycled water and saline water). The results proved that there is a significant increase in crop and water productivity, which irrigated with MTW.

Abd EI Majed [14] studied the effect of using MTW and irrigation periods for two soils with different alternate sodium ratios on the surface hardness. Results showed that irrigation with MTW reduced the hardness of the surface crust, as well as its ability to remove the negative effect of sodium by improving the soil properties.

Al-Rubaie et al. [15] discussed the effect of magnetically treated irrigation water on the vegetative and flower growth characteristics of herbaceous plants. The results showed that, irrigation with MTW led to significant increase in the vegetative growth characteristics, plant height, branches' number, paper area and total amount of chlorophyll, also there was a significant increase in the flower growth characteristics

Hozayn et al. [16] reported that, the utilization of magnetized water has the ability to improve yield and quality of sugar beet crop and water use efficiency under recently reclaimed sandy soil.

Kamorudeen and Ayodele [17] concluded that the magnetic treatment accelerated the growth rate of tomato and the stem diameters were bigger comparing with the non-MTW.

Muzahima et al. [18] proved that, when exposing the seeds of wheat and barley to the MF, the percentage of germination reached $100 \%$ after $9 \mathrm{~d}$ of 
cultivation, in addition, it increased crop productivity and reduce irrigation water. Also, the results showed that the treatment of water magnetically had a greater impact than the treatment of seeds, where the use of treated water (TW) increased water productivity more than using the seed treatments alone.

Surendran et al. [19] reached that there were a beneficial effect of using magnetically treated irrigation water on growth and yield of crops, water and soil properties. The magnetic treatment of irrigation water improved the crop growth and yield of cow pea by $25.8 \%$ and $17.0 \%$, respectively over the control experiment. In addition to the improvement in some water properties values; electrical conductivity, total dissolved solids and salinity levels of all solutions. The use of MTW caused higher soil moisture compared with the control experiment for a different solution of saline and water that contains high soluble calcium and magnesium, respectively.

The previously mentioned studies revealed that the magnetic treatment technique of irrigation water have shown several beneficial effects. It helps to overcome the problem of limited freshwater through the use of non-conventional water source for irrigation, increase the crops growth rate and yield consequently reflect their impact on increasing the water productivity and water use efficiency. In addition, it enhances the chemical and physical soil properties.

However, the extent of these effects remains not well defined. Thus it is essential to know if these effects are the same under different salinity tolerances and various conditions, or depends on the ability of each crop to tolerate salinity.

\section{Materials and Methods}

\subsection{Study Area}

The field experiment was conducted in Wadi El Natroon, El-Behira Governorate, Egypt, experimental station of the Water Management Research Institute. The station is located at latitude $30^{\circ} 25^{\prime} 0^{\prime \prime} \mathrm{N}$, longitude $30^{\circ} 13^{\prime} 0^{\prime \prime}$ E, altitude $25.5 \mathrm{~m}$ above mean sea water level. The study area is characterized by a semi-arid climate with cold winter and hot dry summer. Penman-Monteith method within CropWat 8.0 [20], for Windows, software was used to estimate reference evapotranspiration $\left(\mathrm{ET}_{\mathrm{o}}\right)$ using the station's metrological data shown in Table 1.

\subsection{Experimental Design}

In order to evaluate the impacts of magnetic water treatment on eggplant (Solanum melomgena L. cv Florida High Bush), faba beans (Vicia faba L. cv Isban) and tomato (Solanum lycopersicon L. cv. Logaen) crops, three experimental groups were conducted. The experiments were carried out during winter seasons 2015-2016 and 2016-2017 in a complete randomized design analysis with four replicates (Fig. 1). The effects of magnetically treated irrigation water on the yield, water productivity and water saving were tested for the three crops having different water salinity tolerance $\left(\mathrm{EC}_{\mathrm{w}}\right)$ 0.7, 1.1 and $1.7 \mathrm{dS} / \mathrm{m}$ for eggplant, faba beans and tomato, respectively. The plot area was

Table 1 Average metrological data for Wadi El Natron station (winter season).

\begin{tabular}{llllllll}
\hline Month & $\begin{array}{l}\text { Min } \\
\text { Temperature } \\
\left({ }^{\circ} \mathrm{C}\right)\end{array}$ & $\begin{array}{l}\text { Max } \\
\text { Temperature } \\
\left({ }^{\circ} \mathrm{C}\right)\end{array}$ & $\begin{array}{l}\text { Humidity } \\
(\%)\end{array}$ & $\begin{array}{l}\text { Wind speed } \\
(\mathrm{m} / \mathrm{h})\end{array}$ & $\begin{array}{l}\text { Sun shine } \\
(\mathrm{h})\end{array}$ & $\begin{array}{l}\text { Rainfall } \\
(\mathrm{mm} / \mathrm{month})\end{array}$ & $\begin{array}{l}\mathrm{ET}_{\mathrm{o}} \\
(\mathrm{mm} / \mathrm{day})\end{array}$ \\
\hline November & 17.9 & 23.9 & 62 & 4 & 10.7 & 2.2 & 2.05 \\
December & 14.4 & 20.1 & 62 & 5 & 10.1 & 0.6 & 1.43 \\
January & 12.4 & 18.5 & 62 & 5 & 10 & 1.6 & 1.47 \\
February & 11.9 & 18.9 & 59 & 5 & 11 & 1.2 & 2.07 \\
March & 13 & 21.4 & 57 & 5 & 11.8 & 0.0 & 3.00 \\
April & 15.3 & 24.6 & 55 & 5 & 13 & 2.8 & 4.08 \\
May & 18.2 & 27.8 & 54 & 4 & 14 & 0.0 & 4.95 \\
\hline
\end{tabular}




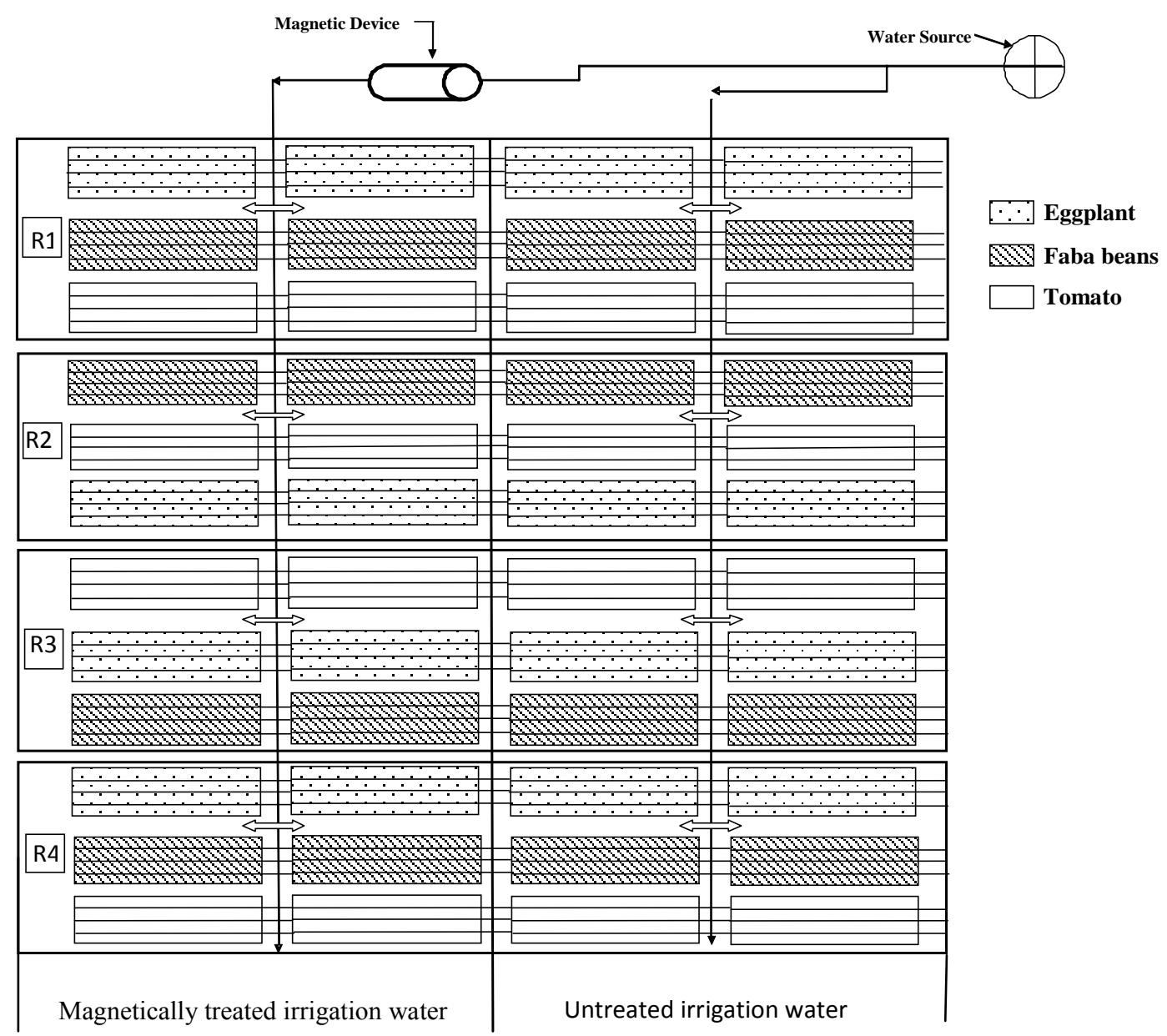

Fig. 1 Experimental design layout.

$20 \mathrm{~m}^{2}(4 \mathrm{~m} \times 5 \mathrm{~m})$. A homogenous common faba bean seeds were cultivated with distance $20 \mathrm{~cm} \times 70 \mathrm{~cm}$ apart while eggplant and tomato were transplanted under plastic cover with distance $50 \mathrm{~cm} \times 70 \mathrm{~cm}$ apart. Agricultural operations and fertilizers of nitrogen, phosphorus and potassium (NPK) were applied for all blocks in accordance with the instructions recommended in agricultural publications [21].

\subsection{Data Collection and Analysis}

\subsubsection{Soil Chemical Analysis}

Soil samples were taken before the experiment, the texture prevailing is sandy soil texture $(92 \%$ sand, $5 \%$ silt and $3 \%$ clay). Soil chemical analysis was performed for different soil layers at the beginning of the crops cycle at the root levels every $20 \mathrm{~cm}$ up to 60 $\mathrm{cm}$ depth. Table 2 lists soil analysis results before cultivation. Soil pHs were also determined at the end of the crops cycle.

\subsubsection{Water Chemical Analysis}

In the experimental site, a groundwater borehole is the main source for irrigation. The results of water chemical analysis are shown in Table 3. Based on the chemical analysis, the water is classified as saline water. To determine the impacts of magnetic treatment of saline water for each plant species, two types of water were used; TW by a magnetic device and UW.

2.3.3 Irrigation System and Water Relations

Drip irrigation method was used in watering. Laterals drip GR lines are made of polyethylene with diameter $16 \mathrm{~mm}$, each of main and sub-main lines are made from PVC with diameter 160, 110 and $90 \mathrm{~mm}$, respectively. The distance between emitters is $0.3 \mathrm{~m}$ with $4 \mathrm{~L} / \mathrm{h}$ discharge. 
Table 2 Soil chemical analysis of Wadi EL Natroon site at the beginning of the experiment*.

\begin{tabular}{|c|c|c|c|c|c|c|c|c|}
\hline \multirow{2}{*}{ Soil layer $(\mathrm{cm})$} & \multirow{2}{*}{$\begin{array}{l}\text { Electrical conductivity } \\
\text { (EC) }(\mathrm{dS} / \mathrm{m}) \text { at } 25^{\circ} \mathrm{C}\end{array}$} & \multicolumn{4}{|c|}{ Soluble cations $(\mathrm{mg} / \mathrm{L})$} & \multicolumn{3}{|c|}{ Soluble anions $(\mathrm{mg} / \mathrm{L})$} \\
\hline & & $\mathrm{Ca}^{2+}$ & $\mathrm{Mg}^{2+}$ & $\mathrm{Na}^{+}$ & $\mathrm{K}^{+}$ & $\mathrm{CO}_{3}{ }^{2-}$ & $\mathrm{HCO}_{3}^{-}$ & $\mathrm{Cl}^{-}$ \\
\hline $0-20$ & 1.7 & 156.7 & 76.3 & 37.5 & 16 & 0 & 60.9 & 113.5 \\
\hline $20-40$ & 1.4 & 190.3 & 40.85 & 48.5 & 20 & 0 & 61 & 127.5 \\
\hline $40-60$ & 2.3 & 212.5 & 58 & 62.5 & 21 & 0 & 73 & 184.5 \\
\hline
\end{tabular}

${ }^{*}$ The samples were analyzed in Central Laboratory for Environmental Quality Monitoring (CLEQM), National Water Research Center.

Table 3 Chemical water analysis for groundwater borehole in Wadi EL Natroon*.

\begin{tabular}{lll}
\hline Parameter & Unit & Value \\
\hline Physical parameters & & \\
\hline $\mathrm{pH}$ & $\mathrm{mg} / \mathrm{L}$ & 8.32 \\
Carbonate $\left(\mathrm{CO}_{3}{ }^{2-}\right)$ & $\mathrm{mg} / \mathrm{L}$ & 26.4 \\
Bicarbonate $\left(\mathrm{HCO}_{3}{ }^{-}\right)$ & $\mathrm{mg} / \mathrm{L}$ & 153.7 \\
Total alkalinity & $\mathrm{mmhos} / \mathrm{cm}$ & 180.1 \\
Electrical conductivity (EC) & $\mathrm{mg} / \mathrm{L}$ & 7.280 \\
Total suspended solids (TSS) & $\mathrm{mg} / \mathrm{L}$ & 4.0 \\
Total dissolved solids (TDS) & & $2,996.0$ \\
\hline Major cations & $\mathrm{mg} / \mathrm{L}$ & \\
\hline Calcium $\left(\mathrm{Ca}^{2+}\right)$ & $\mathrm{mg} / \mathrm{L}$ & 208.03 \\
Potassium $\left(\mathrm{K}^{+}\right)$ & $\mathrm{mg} / \mathrm{L}$ & 16 \\
Magnesium $\left(\mathrm{Mg}^{2+}\right)$ & $\mathrm{mg} / \mathrm{L}$ & 55.2 \\
Sodium $\left(\mathrm{Na}^{+}\right)$ & & 700 \\
\hline
\end{tabular}

*The samples were analyzed in Central Laboratory for Environmental Quality Monitoring (CLEQM), National Water Research Center.

The irrigation schedule was applied for the selected crops. The volume of water used in irrigation was based on $\mathrm{m}^{3} /$ ha. Total irrigation water $\left(\mathrm{m}^{3} / \mathrm{ha} /\right.$ season) and irrigation requirements $\left(\mathrm{m}^{3} /\right.$ ha/interval) for the crops were calculated using the formula of Vermeiren and Jobling [22] as follows:

$$
I R c=\frac{\left[\left(E T_{0} \times K_{C}\right) \times D d\right]+L f}{E_{S}}
$$

where $I R c=$ calculated irrigation water requirements, $\mathrm{mm} /$ interval; $E T_{o}=$ evapotranspiration, $\mathrm{mm} /$ day; $K_{c}=$ crop coefficient [23]; $D d=$ time intervals; $E_{s}=$ system efficiency, $\% ; L f=$ leaching fraction.

Water productivity was used to evaluate the different irrigation water treatments. Water productivity is the yield $/ \mathrm{m}^{3}$ of total water applied [24-26]:

Water productivity $\left(\mathrm{kg} / \mathrm{m}^{3}\right)=\frac{\text { Yield }(\mathrm{kg} / \mathrm{ha})}{\text { Total water used }\left(\mathrm{m}^{3} / \mathrm{ha}\right)}$

\subsubsection{Plant Measurements}

Plant measurements were taken for each crop: eggplant (fruit number per plant, fruit weight and yield (ton/ha)); faba beans (pod number per plant, number of seeds per pod, root weight (g), root nodes weight and yield (ton/ha)) and tomato (number of fruits per plant, $\mathrm{pH}$ in fruit and yield (ton/ha)).

\subsection{Data Analysis}

\subsubsection{Statistical Analysis}

In order to perform statistical analysis and evaluate the overall variability of the data, the $F$ values of the ANOVA were applied, in addition to the least significant difference (LSD) test at significant levels 0.01 and 0.05 to indicate the significance.

\subsubsection{Economic Analysis}

The magnetic treatment technique in irrigation at the experimental site was compared on the basis of gross margins. The procedure adopted by Chaudhry et al. [27] for estimating and subsequently apportioning the cost and returns of various budget items was used in this study. This method does not account for the 
total fixed cost, only variable cost and in this research irrigation investment costs as well. Although the magnetic instrument has longer useful life than one season, the gross margin for one year was estimated. It is to be stated that all costs and revenues were calculated based on local Egyptian market and Egyptian currency (LE). This will not affect the results as the final comparison will be presented as ratios. The formula used to calculate the gross margins is:

Gross Margin $(\mathrm{GM})=$

$$
\text { Total revenue (TR)- }\left\{\begin{array}{l}
\text { Total variable cost (TVC)+} \\
\text { Irrigation investment costs }
\end{array}\right\}
$$

Total variable costs which include land preparation, seed, fertilizers, labor costs etc., were considered the same in both experimental treatments (MTW and non-MTW) except price of magnetic device. This is because much of the water savings from the irrigation systems will be reflected in costs.

\subsubsection{Cost Analysis}

\subsubsection{Irrigation System Cost}

Capital irrigation system cost was calculated using the current dealer prices of equipment and installation according to 2016-2017 price level.

\subsubsection{Fixed Costs}

The annual fixed cost was calculated using the following equation:

$$
\text { F.C }=D+I+T
$$

where $F . C=$ annual fixed cost (LE/year); $D=$ depreciation (LE/year); $I=$ interest (LE/year); $T=$ taxes and overhead ratio (LE/year).

\subsubsection{Depreciation (D)}

The depreciation was determined by the following equation:

$$
D=\frac{I \cdot C-S v}{E \cdot L}
$$

where I.C $=$ the element initial cost of irrigation system (LE); $S v=$ salvage value after depreciation (LE); $E . L=$ the element expected life, year.

\subsubsection{Capital Interest (I)}

Capital interest was calculated using the following equation:

$$
I=\frac{I . C \times 1.10}{2} \times I . R
$$

where I.R. $=$ the interest, rate/year (taken 14\%). Taxes and overheads ratio were taken $2.0 \%$ from initial cost.

\subsubsection{Running Cost (RC)}

The annual running cost was estimated as follows:

$$
R C=E . C+(R \& M)+L . C
$$

where $R C=$ annual running cost (LE/year); L.C = labor costs (LE/year). E.C = energy costs (LE/year); $R \& M=$ repairs and maintenance costs (LE/year).

\subsubsection{Labor Cost (L.C)}

Labor cost was calculated using the following equation:

$$
\text { L.C }=T \times N \times P
$$

where $L . C=$ annual labor cost (LE/year); $T=$ annual irrigation time (h/year); $N=$ labor number for ha; $P=$ labor cost (LE/h).

\subsubsection{Energy Cost (E.C)}

Some treatments used an electrical motor; its cost was calculated using the following formula:

$$
\text { E. } C=B p \times T \times P r
$$

where $E . C=$ energy costs for electricity (LE/year); Bp $=$ the brake power $(\mathrm{kW}) ; T=$ the annual operating time (h); $P r=$ cost of electrical power $(\mathrm{LE} / \mathrm{kW} / \mathrm{h})$.

The brake horse power required $(B p)$ was calculated using the following equation [28]:

$$
B p=\frac{Q \times T_{D H}}{C \times E_{\text {overall }}}
$$

where $Q=$ total discharge rate $(\mathrm{L} / \mathrm{s}) ; T_{D H}=$ total dynamic head (m); $C=$ conversion coefficient to energy unit, 102 [29]; $E_{\text {overall }}=$ overall efficiency $(67.5 \%$ for pump drive by electric motor).

The total cost of lifting water $/ \mathrm{m}^{3}$ was calculated as:

$$
\text { Total cost of lifting water } / \mathrm{m}^{3}=\frac{\text { Total costs }(\mathrm{LE} / \mathrm{h})}{\text { Discharge }\left(\mathrm{m}^{3} / \mathrm{h}\right)}
$$

\subsubsection{Repairs and Maintenance Costs $(R \& M)$}

It was taken about $2 \%$ of the initial cost, under drip irrigation. 


\subsubsection{Income}

The total income was evaluated using the following formula:

$$
\text { Income }=Y t \times d
$$

where $Y t=$ total yield (ton); $d=$ yield price (LE/ton).

\subsubsection{Net Profit}

The economical profit of yield was determined as [30]:

$$
P=\text { Income }-C t
$$

where $P=$ net profit $(\mathrm{LE} / \mathrm{ha}) ; C t=$ total production costs (LE/ha).

After the above calculations were used to estimate the gross margins of the crops in the growing seasons, the per hectare total costs and total incomes were used to estimate the net profits of magnetic irrigation water treatment and untreated irrigation water at the experimental station.

\section{Results and Discussion}

\subsection{Effect of MTW on Crops Yield}

Results showed that, there were differential positive effects of magnetically treatment of irrigation water on the yield of the three crops, but the values of these effects vary between them.

\subsubsection{Eggplant}

The results in Table 4 showed that, the irrigation with MTW has significantly improved crop yield $(p<$ 0.01) of the plots irrigated with TW. Thus, the highest yield was produced under TW which was about 34.05 ton/ha versus 23.23 ton/ha for UW. Eggplant fruit weight was affected significantly by irrigation with MTW at the 0.01 probability level, while the increase in number of fruits per plant was significant at 0.05 probability level. The salinity of the irrigation water caused decreases in fruit weight. The highest fruit weight $(1.36 \mathrm{~kg} /$ plant $)$ was obtained with $\mathrm{TW}$, while low value was observed with UW $(0.7 \mathrm{~kg} /$ plant $)$. The yield reduction was $31.8 \%$ for UW which agreed with the finding of Chartzoulakis and Loupassaki [31] who reported yield decrease of $23 \%, 41 \%, 69 \%$ and $88 \%$ for EC 3.4, 5.7, 9.4 and $12.2 \mathrm{dS} / \mathrm{m}$ treatments, respectively. This is in accordance with the classification proposed by Maas and Hoffmann [32], where the eggplant is considered sensitive to salinity with a low threshold $\mathrm{EC}_{\mathrm{w}}$ value $(0.7 \mathrm{dS} / \mathrm{m})$. For the physiological characteristics of the fruits, there is no significant in moisture content (\%) between TW and UW while there was high significant difference $(p<$ $0.01)$ in the carbohydrate and protein percentage and amount of nitrogen (Table 4).

\subsubsection{Faba Beans}

Irrigation with TW improved significantly $(p<0.01)$ faba beans growth (number of pods per plant) and yield quality (number and weight of seed per plant) which reflected superiority of productivity as shown in Table 5. Total yield obtained for TW was 6.92 compared to 4.25 (ton/ha) for UW. Highly significant TW effects $(p<0.01)$ were appeared on root weight and the amount of the root nodes per plant compared to the UW. Analyzing the morphological characteristics for faba beans seeds the results showed that, there is no significant in carbohydrate ratio (\%) between TW and UW using $F$-test but it was significant with LSD at level 0.05 , and there were high significant

Table 4 Significant level among the treatments treated water (TW) and untreated water (UW) in physiological

\begin{tabular}{|c|c|c|c|c|}
\hline $\begin{array}{lll} & \text { Element } \\
\text { Treatment } & \end{array}$ & Moisture content $(\%)$ & Carbohydrate (\%) & Protein $(\%)$ & Nitrogen $(\mathrm{mg} / \mathrm{kg})$ \\
\hline TW & 76.5 & 32.1325 & 2.9125 & $4,488.975$ \\
\hline UW & 75.5 & 21.7975 & 1.8125 & $2,370.925$ \\
\hline$F$-test & n. s. & $* *$ & $* *$ & $* *$ \\
\hline$t$-test & n. s. & $* *$ & $* *$ & $* *$ \\
\hline
\end{tabular}
characteristics for the eggplant fruits.

$F$ and $t$ values $*=p<0.05, * *=p<0.01$. Data presented are the means of four replicates.

n. s.: not significant. 
Table 5 Significant level among the treatments TW and UW in physiological characteristics for the faba beans.

\begin{tabular}{llllll}
\hline Treatment & Crops & $\begin{array}{l}\text { Number of pods per } \\
\text { plant }\end{array}$ & $\begin{array}{l}\text { Seed weight per } \\
\text { plant }(\mathrm{g})\end{array}$ & $\begin{array}{l}\text { Root nodes per plant } \\
(\mathrm{g})\end{array}$ & $\begin{array}{l}\text { Carbohydrate }(\%) \\
(\mathrm{mg} / \mathrm{kg})\end{array}$ \\
\hline TW & 47.75 & 767.21 & 115.5 & 45.8275 & 9.725 \\
UW & 32.25 & 315.19 & - & 42.645 & 4.625 \\
F-test & $* *$ & $* *$ & $* *$ & n. s. & $* *$ \\
$t$-test & $* *$ & $* *$ & $* *$ & $*$ & $* *$ \\
\hline
\end{tabular}

$F$ and $t$ values $*=p<0.05, * *=p<0.01$. Data presented are the means of four replicates.

n. s.: not significant.

effect $(p<0.01)$ in the amount of total phosphors $(\mathrm{mg} / \mathrm{kg})$. The changes of $\mathrm{pH}$ for TW resulted in the accentuation of biological activity in plants and consequently influenced the growth rate of plants. Furthermore, the magnetic treatment might have resulted in faster activations of enzymes and hormones during the growth process which probably caused an improvement in the mobilization and transportation of nutrients [33]. In addition, the magnetic treatment could act on the soil/water interface which may have led to destabilization of air molecules, thus disturbing the ionic balance between the adsorbed negative ions and counter ions [34].

\subsubsection{Tomato}

For tomato, the total yield obtained for TW was 77.5 compared to 50.76 (ton/ha) for UW. The higher values of physiological parameters (ratios of carbohydrates and proteins) were observed with the UW (Table 6). This result can be explained by the increase of the enzymatic activity under salt stress conditions, which increases the proportion of carbohydrates and protein in the tissues of plant especially in fruits; this is consistent with the results obtained by Jiang et al. [35]. Previous studies proved that there is a decrease in the $\mathrm{pH}$ of fruit juice by increasing the salinity of irrigation water. This decrease is referred to the transfer of inorganic acids under saline stress to fruits, especially cations, which leads to an increase in the ratio of cation to anion in the tomato fruits. This increase causes the increase of total acidity which induces the reduction of $\mathrm{pH}$ value [36-41]. The data obtained showed that irrigation with TW resulted in decrease in $\mathrm{pH}$ value in the tomato fruits than the UW. This means that the effect of magnetic treatment has stronger influence than salt stress. For both treatments, there is an increase in fruits acidity but it was more significantly for TW as shown in Table 6 .

\subsection{Effect of MTW on Soil pH}

Soil analysis showed that there was a change in the $\mathrm{pH}$ values of soil samples before and at the end of the experiments for different crops (Fig. 2). The magnetic treatment of irrigation water led to a decrease in $\mathrm{pH}$ values and reached neutral values in some locations, especially the area cultivated with the faba beans (between 7.05 and 7.08). This medium is appropriate to encourage the growth of bacterial root nodes on the capillaries of the root, which was reflected in significant increase in faba beans productivity. For the eggplant the soil $\mathrm{pH}$ irrigated with TW reached 7.08-7.15 while for tomato it reached 7.16-7.28 at the end of the experiments.

\subsection{Effect of MTW on Water Relations}

\subsubsection{Total Applied Irrigation Water}

The results showed that, irrigation with MTW has a positive effect on the rate of plants growth, which led to the curtailment of stage periods of crop and thus the duration of the crop, which was reflected to the crop water consumptive. The total irrigation water used by eggplant, faba beans and tomato plants during the growing period varied considerably with the type of irrigation water used. However, the magnetic treatment of the saline water has a significant effect on the total water consumed by the three crops during the 
Table 6 Significant level among the treatments TW and UW in physiological characteristics for the tomato fruits.

\begin{tabular}{|c|c|c|c|}
\hline $\begin{array}{ll}\text { Treatment } & \text { Elements } \\
\end{array}$ & Carbohydrate (\%) & Protein $(\%)$ & $\mathrm{pH}$ \\
\hline TW & 26.97 & 2.725 & 3.68 \\
\hline UW & 30.04 & 3.9475 & 4.36 \\
\hline$F$-test & $* *$ & $* *$ & $* *$ \\
\hline$t$-test & $* *$ & $* *$ & $* *$ \\
\hline
\end{tabular}

$F$ and $t$ values $*=p<0.05, * *=p<0.01$. Data presented are the means of four replicates.

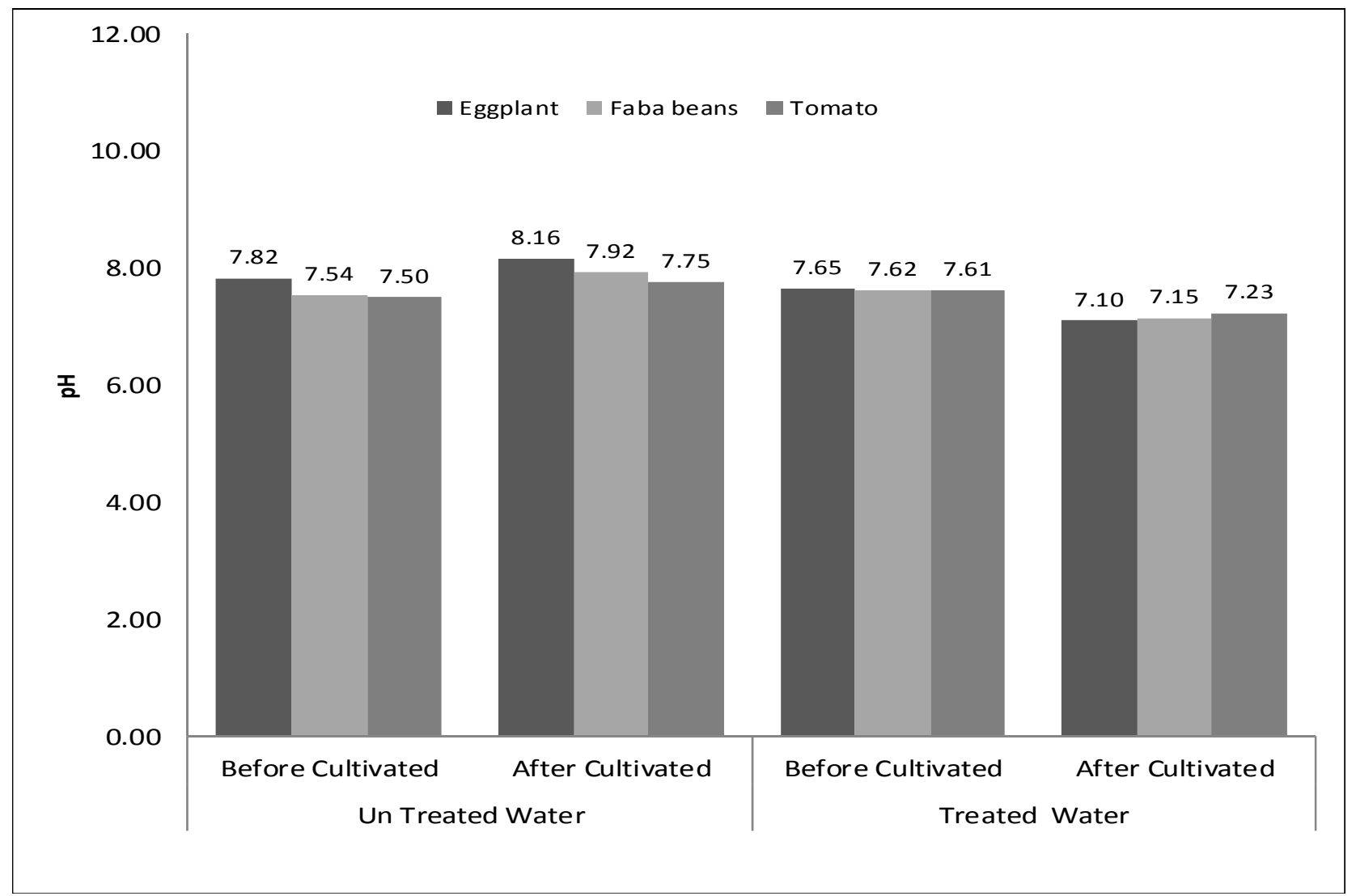

Fig. 2 Soil pH before and after cultivation.

growing period as compared with the untreated saline irrigation water (Fig. 3). It is an important finding of this study, particularly indicating that the magnetic treatment of salty irrigation water has direct effect on duration of growing period for each crop, consequently on the water used and water productivity. This is in agreement with Pietruszewski [42] who proved that MF can affect the germination traits of different seeds including tomato and broad been, and plays a significant role on germination percentage. In line with these findings, Pietruszewski [43] revealed that wheat seeds treated by MF can speed up germination compared with the untreated samples. Also, Pietruszewski [44] proved that, wheat seeds treated by MF can accelerate the germination rate compared with the untreated seeds.

\subsubsection{Water Productivity}

Water productivity for different crops as influenced by type of irrigation water is presented in Table 7 . The highest water productivity was achieved under TW for faba beans with increasing ratio 1.88 compared to UW followed by tomato with 1.78 and then the eggplant 1.65. This is related to tolerance of each crop to the salinity. 


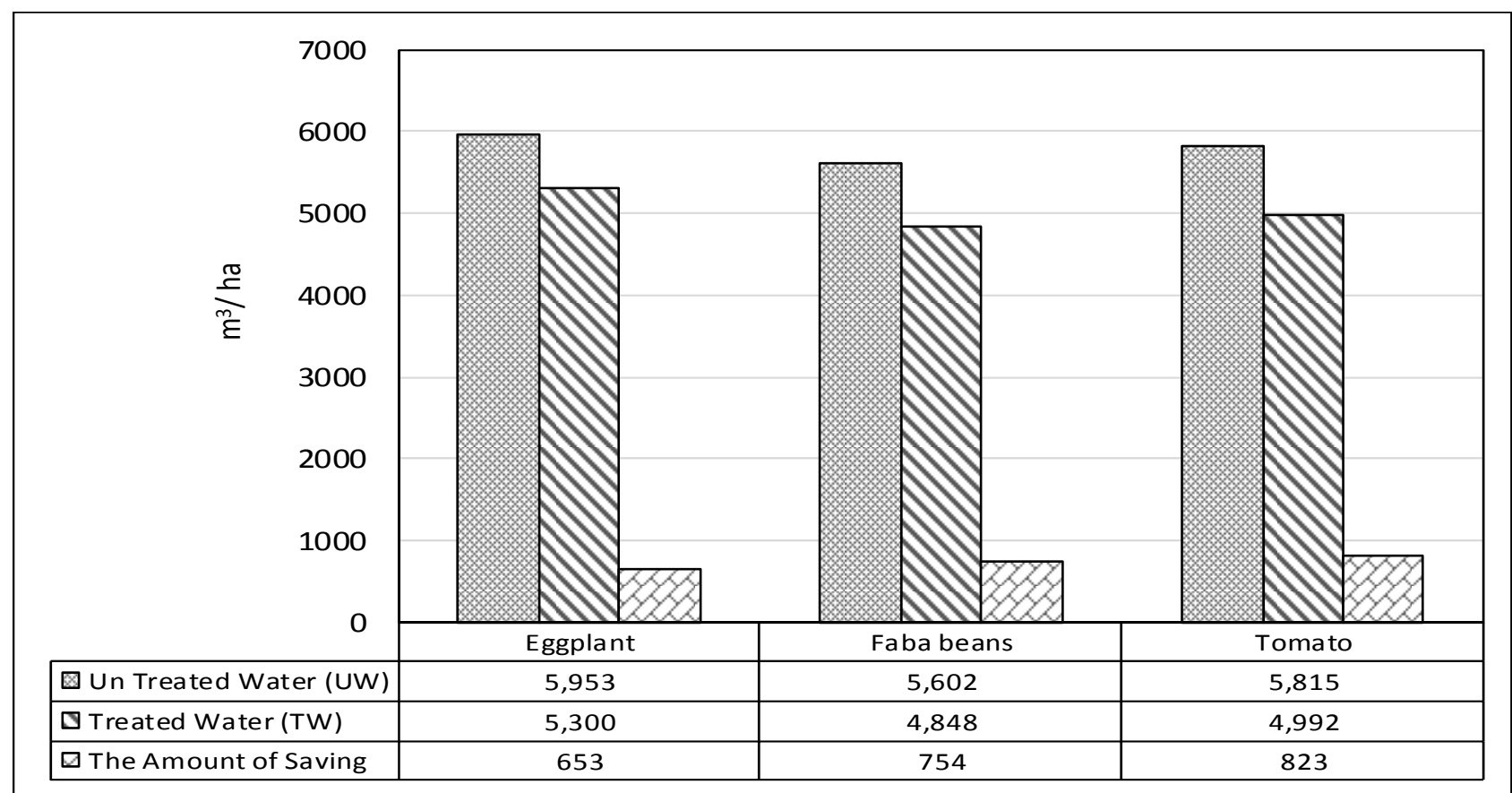

Fig. 3 Applied water for eggplant, faba beans and tomato during the growing period with magnetically treated and un treated saline irrigation water.

Table 7 Water productivity of eggplant, faba beans and tomato under treated and untreated saline irrigation water.

\begin{tabular}{|c|c|c|c|c|c|c|}
\hline \multirow{2}{*}{ Treatment } & \multicolumn{2}{|c|}{ Eggplant } & \multicolumn{2}{|c|}{ Faba beans } & \multicolumn{2}{|c|}{ Tomato } \\
\hline & TW & UW & TW & UW & TW & UW \\
\hline Yield (ton/ha) & 34.05 & 23.23 & 6.92 & 4.25 & 77.5 & 50.76 \\
\hline Applied irrigation water $\left(\mathrm{m}^{3} / \mathrm{ha}\right)$ & 5,300 & 5,953 & 4,848 & 5,602 & 4,992 & 5,815 \\
\hline Water productivity $\left(\mathrm{kg} / \mathrm{m}^{3}\right)$ & 6.42 & 3.90 & 1.43 & 0.76 & 15.52 & 8.73 \\
\hline Ratio of increasing of water productivity & 1.65 & & 1.88 & & 1.78 & \\
\hline
\end{tabular}

Table 8 Economic analysis for eggplant, faba beans and tomato production under treated and untreated saline irrigation water (LE/ha).

\begin{tabular}{|c|c|c|c|c|c|c|c|}
\hline \multirow{2}{*}{$\begin{array}{l}\text { Irrigation water } \\
\text { Crops }\end{array}$} & \multirow{2}{*}{ Unit } & \multicolumn{3}{|c|}{ TW } & \multicolumn{3}{|c|}{ UW } \\
\hline & & Eggplant & Faba beans & Tomato & Eggplant & Faba beans & Tomato \\
\hline Applied irrigation water & $\mathrm{m}^{3} / \mathrm{ha}$ & 5,300 & 4,848 & 4,992 & 5,953 & 5,602 & 5,815 \\
\hline Amount of water saving & $\mathrm{m}^{3} / \mathrm{ha}$ & 653 & 754 & 823 & & & \\
\hline Ratio of water saving & $\%$ & 11.0 & 13.5 & 14.2 & & & \\
\hline Yield & ton/ha & 34.05 & 6.92 & 77.5 & 23.23 & 4.25 & 50.76 \\
\hline Increase in productivity & $\%$ & 46.6 & 62.8 & 52.7 & & & \\
\hline Additional irrigated area & $\%$ & 12.3 & 15.5 & 16.5 & 0.0 & 0.0 & 0.0 \\
\hline Yield of additional irrigated area & ton & 1.69 & 0.43 & 5.17 & 0 & 0 & 0 \\
\hline Total yield & ton & 15.5 & 3.23 & 36.53 & 9.4 & 1.72 & 20.54 \\
\hline Yield ratio increase & $\%$ & 64.6 & 88 & 77.9 & & & \\
\hline Irrigation cost & LE & $6,218.2$ & $6,011.8$ & $6,047.5$ & $7,258.1$ & $7,097.3$ & $7,478.4$ \\
\hline Magnetic device cost & LE/year & 400 & 400 & 400 & 0 & 0 & 0 \\
\hline Other practices & LE & $8,116.8$ & $7,276.8$ & 24,240 & $8,116.8$ & $7,276.8$ & 24,240 \\
\hline Original total cost & LE & 14,735 & 13,689 & 30,688 & 15,375 & 14,375 & 31,718 \\
\hline Total revenue & LE & 59,477 & 37,778 & 114,211 & 40,594 & 23,399 & 74,808 \\
\hline Gross margin & LE & 44,742 & 24,090 & 83,524 & 25,219 & 9,025 & 43,089 \\
\hline Net return/water unit & $\mathrm{LE} / \mathrm{m}^{3}$ & 7.52 & 4.81 & 12.42 & 4.2 & 1.6 & 5.06 \\
\hline
\end{tabular}




\subsection{Economic Evaluation}

The total cost of using TW was LE. 14,735 for eggplant, 13,688 for faba beans and 30,687 for tomato which was nearly equal to the total cost of using UW. For all crops, the higher values of revenue (LE. 59,476, 37,778 and 114,211 for eggplant, faba beans and tomato, respectively) were obtained using MTW. Thus the MTW allows obtaining the higher gross margin compared to the UW, at LE. 44,742, 24,089 and 83,524 for the three crops, respectively. Table 8 depicts the economic analysis per hectare for crops production.

While the use of magnetic device has engendered the increase of irrigation investment costs and consequently total cost, the total variable cost of the irrigation with TW remains lower than that for the irrigation with UW for all selected crops. This is mainly due to decreases in irrigation operation cost (amount and growing period) per hectare, which in turn decreased the expenses of operations and fuel consumption and increased the life time of the pumps and pipelines. Therefore, the irrigation cost using this technique allows more efficient use of irrigation inputs as shown in Table 8.

The ratios of the gross margins obtained from using TW to that from using UW were 1.75, 2.61 and 2.11 for eggplant, faba beans and tomato, respectively. The ratios of the net return per water unit obtained from using TW to that from using UW were 1.97, 3.0 and 2.45 for eggplant, faba beans and tomato, respectively.

\section{Conclusions}

The effect of magnetic treatment of saline irrigation water depends not only on the extent tolerance of the crop to salinity, but also on the changes occurs to the soil to suit crop germination and growth. This research conclusion may be summarized as follows:

Magnetic treatment decreases soil $\mathrm{pH}$ to nearly reach neutral especially the soil planted by faba beans. It decreases crop growing period and saves more irrigation water. The MTW increases the water productivity by $1.65,1.88$ and 1.7 for eggplant, faba beans and tomato, respectively. It also leads to water savings of $11 \%, 13.5 \%$ and $14.2 \%$ for the three crops, respectively. As a result the net profit increased. The ratios of the net return per water unit obtained from using magnetic treatment technique to that from using UW are 1.97, 3.0 and 2.45 for eggplant, faba beans and tomato, respectively.

\section{Recommendations}

It is recommended to conduct more research to study the effect of MF strength and its position in the irrigation system on the efficiency of applying this technique. Also study the time of irrigation water flow to estimate its effect on improving the properties of water. There is a need to evaluate the application of this technique using different irrigation systems.

\section{References}

[1] Ayars, J. E., Hutmacher, R. B., Schoneman, R. A., Vail, S. S., and Pflaum, T. 1993. "Long Term Use of Saline Water for Irrigation.” Irrigation Science 14 (1): 27-34.

[2] Hakkwan, K., Hanseok, J., Jihye, J., and Seungjong, B. 2016. "Effects of Irrigation with Saline Water on Crop Growth and Yield in Greenhouse Cultivation." Water 8 (4): 127.

[3] Zhu, Y., Sheng, G., Han, J., and Liu, W. 1986. "Studies on the Effectiveness of Magnetized Water in Improving Saline Soils." Irrigation and Drainage Abstracts 012-01629.

[4] Oleshko, P., Vadyunina, F., Zhilyaya, A., and Trukhin, I. 1981. "Effect of a Magnetic Field on the Properties of Soil and Plants." Pochvovedeniye 7: 91-8.

[5] Takachenko, P. 1995. "The Application of Magnetic Technology in Agriculture.” Magnetizer 9-11.

[6] Takachenko, Y., and Ojil, H. 1997. "Magnetic and Environment." Magnetic Technologic 11 (2): 44-51.

[7] Hilal, M. H., and Hilal, M. M. 2000. "Application of Magnetic Technologies in Desert Agriculture: I. Seed Germination and Seedling Emergence of Some Crops in a Saline Calcareous Soil.” Egypt Journal of Soil Science 40 (3): 413-22.

[8] Blake, W. 2000. "Physical and Biological Effect of Magnet." In The Art of Magnetic Healing, edited by Santwani, M. T. India: B. Jain. India Gyaa. Com. 

Yield and Water Productivity for Some Crops

[9] Aladjadjiyan, A. 2002. "Study of the Influence of Magnetic Field on Some Biological Characteristics of Zea mais." Journal of Central European Agriculture 3 (2): 89-94.

[10] Hasan, K. M., Fahad, A. A., Falih, A. S., and Rashed, T. I. 2005. "Magnetic Conditioning of Saline Water Characteristics for Irrigation: Sunflower." The Iraqi Journal of Agricultural Science 36 (1): 23-8. (in Arabic)

[11] Fahad, A. A., Hasan, K. M., Falih, A. S., and Rashed, T. I. 2005. "Magnetic Conditioning of Saline Water Characteristics for Irrigation Crops: Corn and Wheat." The Iraqi Journal of Agricultural Science 36 (1): 29-34. (in Arabic)

[12] Al-jothery, A., and Abdulsada, J. 2015. "The Effect of Magnetic Water Treatment and KSC Sulfacid Fertigation in Leaching Salts Soil Efficiency." AL-Qadisiya Journal for Basic Sciences 20 (1): 30-7. (in Arabic)

[13] Maheshwari, B. L., and Grewalm, S. 2009. "Magnetic Treatment of Irrigation Water: Its Effects on Vegetable Crop Yield and Water Productivity." Agric. Water Manag. 96: 1229-36.

[14] Abd El Majed, F. 2012. "The Effect of Used Magnetic Water and Periods of Irrigation on Crust Hardness for Two Soils Differed in Their Exchangeable Sodium Percentage." Academic Scientific Journals 25 (4): A1-A9. (in Arabic).

[15] Al-Rubaee, M., Al-Chalaby, S., and Al-Dulaymy, H. 2012. "Effect of Magnetized Irrigation Water and Spraying by Salicylic Acid (SA) on Growth and Flowering of Callistephus chinensis L." Kufa Agricultural Sciences Journal 4 (1): 210-20. (in Arabic)

[16] Hozayn, M., Abd El Monem, A., Abdelraouf, E., and Abdalla, M. 2013. "Do Magnetic Water Affect Water Use Efficiency, Quality and Yield of Sugar Beet (Beta vulgaris L.) Plant under Arid Regions Conditions." Journal of Agronomy 12: 1-10.

[17] Kamorudeen, Y., and Ayodele, O. 2015. "Impact of Magnetic Treatment of Irrigation Water on the Growth and Yield of Tomato." Notulae Scientia Biologicae 7 (3): 345-8.

[18] Muzahima, A., ElAni, I., and Marae, N. 2015. "Effect of Magnetic Techniques Applications in the Treatment of Saline Water Wells for Irrigating Wheat and Barley Plant in Northern Iraq." Journal of Babylon University/Basic and Applied Sciences 23 (1): 278-86. (in Arabic)

[19] Surendran, U., Sandeep, O., and Joseph, J. 2016. "The Impacts of Magnetic Treatment of Irrigation Water on Plant, Water and Soil Characteristics." Agricultural Water Management 178: 21-9.

[20] FAO. 2009. "CropWat 8.0 for Windows User Guide." FAO, Rome, Italy.

[21] Ministry of Agriculture. 2015. "Crops Guidance Bulletin."
Ministry of Agriculture, Egypt. (in Arabic)

[22] Vermeiren, L., and Jobling, G. A. 1980. "Localized Irrigation.” FAO Irrigation and Drainage Paper, No. 36, Rome, Italy.

[23] Doorenbos, J., and Kassam, A. H. 1979. "Yield Response to Water." FAO Irrigation and Drainage Paper, No. 33, Rome, Italy.

[24] Jensen, M. E. 1983. Design and Operation of Farm Irrigation Systems. ASAE, Michigan, USA, 827.

[25] Smith, M. 1993. "CLIMWAT for CROPWAT, A Climate Database for Irrigation Planning and Management." FAO Irrigation and Drainage Paper, No. 49, Rome, Italy, 113.

[26] Walker, D. 1980. Design and Operation of Farm Irrigation System. Englewood Cliffs: Prentice Hall.

[27] Chaudhry, A. M., Ahmad, B., and Chaudhry, M. A. 1992. "Cost of Producing Major Crops in Pakistan 1991-92." Research Report, Department of Farm Management, University of Agriculture, Faisalabad.

[28] Longenbaugh, A., and Duke, R. 1981. "Farm Pumps." In Design and Operation of Farm Irrigation Systems, edited by Jensen, M. E., ASAE Monograph No. 3, St. Joseph, MI. USA, 829.

[29] James, L. G. 1988. "Multi-purpose and Special Uses.” In Principles of Farm Irrigation System Design, Handbook, Washington State University, 405.

[30] Younis, M., Shibon, A., and Aref, O. 1991. "Evaluation of Some Mechanical Methods of Rice Production in Egypt." Journal of Agriculture Engineering 8 (1): 39-49.

[31] Chartzoulakis, K., and Loupassaki, M. H. 1997. "Effects of $\mathrm{NaCl}$ Salinity on Germination, Growth, Gas Exchange, and Yield of Greenhouse Eggplant.” Agric. Water Manag. 32: $214-25$.

[32] Maas, E. V., and Hoffmann, G. J. 1977. "Crop Salt Tolerance-Current Assessment." Journal of the Irrigation and Drainage Division 103 (2): 115-34.

[33] Deia, A. M. 2014. "Effect of Magnetic Water and Depth of Drip Irrigation Water and Yield of Cucumber in Green Houses." Diyala Agricultural Sciences Journal 6 (1): 179-86.

[34] Surendran, U., Sandeep, O., Mammen, G., and Joseph, J. 2013. "A Novel Technique of Magnetic Treatment of Saline and Hard Water for Irrigation and Its Impact on Cow Pea Growth and Water Properties." Int. J. Agric. Environ, Biotech. 6 (1): 85-92.

[35] Jiang, J., Li, L., Lu, W., and Liu, S. 2007. "The Relationship between the Added $\mathrm{NaCl}$ of Different Concentration and the Development of Tomato Fruits under the Soilless Culture." Northern Horticulture 7: 49-51.

[36] Willumsen, J., Petersen, K., and Kaack, K. 1996. "Yield and Blossom-End Rot of Tomato as Affected by Salinity and Cation Activity Ratios in the Root Zone." J. Hort. Sci. 
71 (1): 81-98.

[37] Eltez, R. Z., Tüzel, Y., Gül, A., Tüzel, I. H., and Duyar, H. 2000. "Effects of Different EC Levels of Nutrient Solution on Greenhouse Tomato Growing." ISHS Acta Horticulturae 573: 443-8.

[38] Pascale, S. D., Maggio, A., Fogliano, V., Ambrosino, P., and Ritieni, A. 2001. "Irrigation with Saline Water Improves Carotenoids Content and Antioxidant Activity of Tomato." Journal of Horticultural Science and Biotechnology 76 (4): 447-53.

[39] Pascale, S. D., Maggio, A., Angelino, G., and Graziani, G. 2003. "Effect of Salt Stress on Water Relations and Antioxidant Activity in Tomato." ISHS Acta Horticulturae 613: 39-46.

[40] Beyenne, G. T., and Hunter, A. 2002. "Physiological Response of Tomato from Induced Sodium Chloride
Stress." In Proceedings of the XXVI International Horticultural Congress: Environmental Stress and Horticulture Crops, Toronto, Canada, 11-7.

[41] Abou El-Yazied, A., Shalaby, O. A., El-Gizawy, A. M., Khalf, S. M., and El-Satar, A. 2011. "Effect of Magnetic Field on Seed Germination and Transplant Growth of Tomato." Journal of American Science 7 (12): 306-12.

[42] Pietruszewski, S. T. 1999. "Effect of Alternating Magnetic Field on Germination, Growth and Yield of Plant Seeds.” Inzynieria Rolnicza 5 (11): 209-15.

[43] Pietruszewski, S. T. 1999. "Influence of Pre-sowing Magnetic Bio-stimulation on Germination and Yield of Wheat." Int. Agrophysics 13: 241-4.

[44] Pietruszewski, S. T. 1996. "Effects of Magnetic Bio-stimulation of Wheat Seeds on Germination, Yield and Proteins." Int. Agrophysics 10: 51-6. 